\title{
Foreign Investment: Potential of Growth and Constraints
}

\author{
Tatyana S. Kolmykova ${ }^{1}$, Zinaida V. Chernih ${ }^{1} \&$ Elvira V. Sitnikova ${ }^{1}$ \\ ${ }^{1}$ Southwest State University, Russian Federation \\ Correspondence: Tatyana S. Kolmykova, 50 let Oktyabrya str. 94, Kursk, Russian Federation. E-mail: \\ 0209elvira@mail.ru
}

Received: June 7, 2014 Accepted: July 15, 2014 Online Published: September 28, 2014

doi:10.5539/ass.v10n20p88

URL: http://dx.doi.org/10.5539/ass.v10n20p88

\begin{abstract}
This paper is devoted to the various forms of attracting foreign investment by Russian companies. The analysis of volumes and dynamics of attracting foreign investment was made. The reasons for rejection foreign investors from placing funds in Russian companies were subjected to a critical understanding. The main directions of improvement of management of foreign investment are: the simplification of procedures for obtaining building permits; improving customs administration; increase of availability of energy infrastructure; the development of business environment in the regions; optimization of migratory procedures; tax stimulation; development of the corporate legislation; decrease of administrative barriers; development of criteria for assessing the effectiveness of heads of federal executive bodies to improve the investment climate; cooperation with international development institutions; formation of institutions of improvement the investment climate.
\end{abstract}

Keywords: investment, foreign investment, production efficiency

\section{Introduction}

Developing and strengthening the economic efficiency of enterprises is mostly dependent on the national investment potential, which is generated by a variety of funding sources, including foreign investment. The use of foreign investment is an objective necessity because of the lack of own investment resources, and also due to intensive integration of industrial and economic systems.

In the focus of Russian researchers are constantly various aspects of economic activity of Russian enterprises, public authorities and management connected with attraction of foreign investments. The numerous studies are dedicated to them.

At the same time, the problem is still relevant because of its unsolved and changing operating conditions of both domestic and foreign companies of various activities and economic sectors.

Analysis of volumes and forms of foreign investment, methods of its attracting and related issues are represented in domestic literature. In particular, we must note the works of V. M. Kruglyakova (2010), B. G. Preobrazhenskiy (2008), Y. I. Treshchevskiy (2010), A. V. Stepanchenko (2013), who explored this issue in detail with reference to the period of growing economic situation in the country.

A large number of researches in domestic and foreign literature are devoted to questions of attraction of foreign investments, their influences on national economy. Such foreign economists, as D. Rikardo (1993), Dz. St. Mil (1981), L. Valras (2000), E. Heckscher (2007) and others (Zakrzewska-Bielawska, 2010; Maier, 2002; Matusiak, 2005) were engaged in studying of the international movement of the capital.

\section{Methods}

The total volume of accumulated foreign investment in the Russian economy at the end of 2012 was 362.4 billion dollars, which is $4.4 \%$ more than at the end of the previous year and $64.3 \%$ higher than in 2007 . The largest share in the accumulated foreign capital falls on other investments made on a return basis- $57.1 \%$, the share of direct investments was $37.5 \%$, portfolio investments- $2.4 \%$.

In 2012154.9 billion dollars received to the Russian economy, which is $18.9 \%$ less income 2011. (Figure 1). Of which direct investments- $21.1 \%$ of portfolio investments- $1.2 \%$, other- $86.7 \%$. 


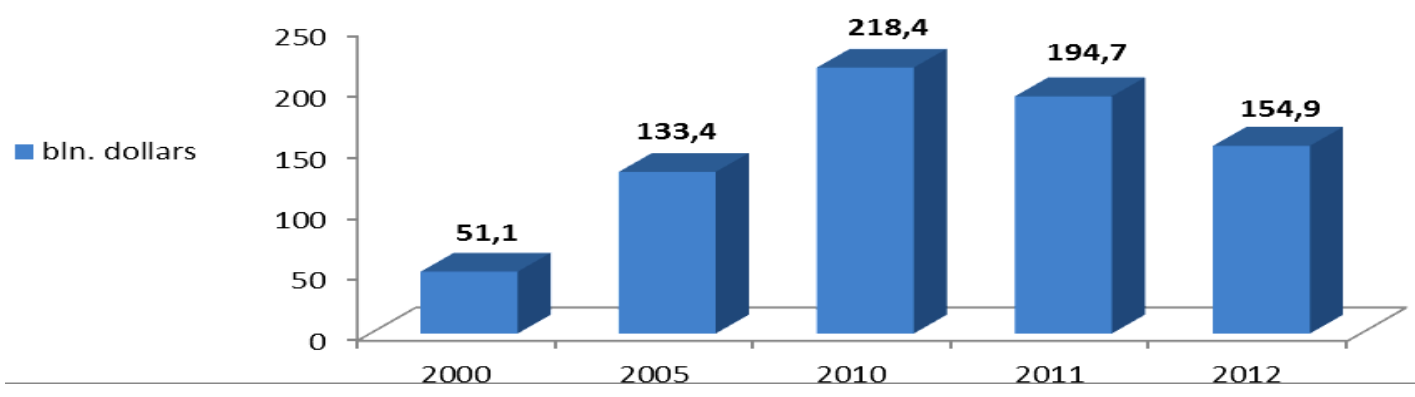

Figure 1. Foreign investments in the fixed capital of Russian organizations, billion dollars

The decrease of foreign investments was noted in total investment (Figure 2). This dynamic is retained even with the elimination of the negative effects of the global financial crisis of 2007-2008.

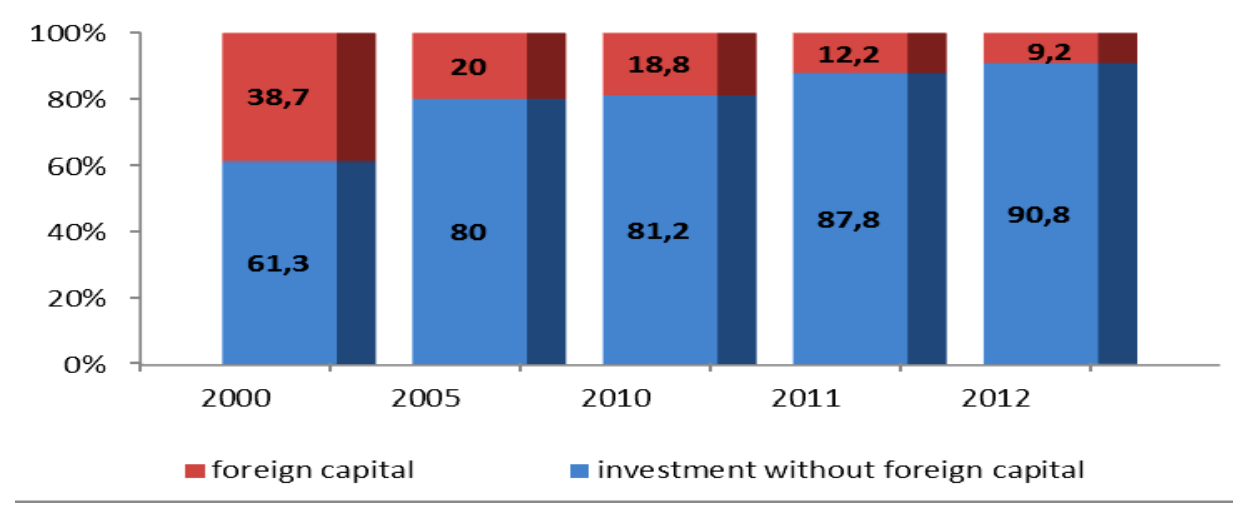

Figure 2. The structure of investments in Russian economy, \%

According to the survey Merril Lynch, conducted among managers of international investment funds, Russia has ranked first place of investment attractiveness of the BRICS countries.

In 2013 Russia takes 112 places on the ease of doing business according to the research by Doing Business, compiled annually by the World Bank, and evaluating business conditions in 189 countries (Table 1).

Table 1. Doing business rating

\begin{tabular}{llllll}
\hline Countries & 2009 & 2010 & 2011 & 2012 & 2013 \\
\hline Belarus & 85 & 64 & 91 & 60 & $58(2) \uparrow$ \\
Brazil & 125 & 124 & 120 & 128 & $132(0)-$ \\
India & 122 & 135 & 139 & 132 & $130(2) \downarrow$ \\
Kazakhstan & 70 & 74 & 58 & 56 & $49(7) \uparrow$ \\
China & 83 & 78 & 87 & 91 & $91(0)-$ \\
Russia & 120 & 116 & 124 & 118 & $112(6) \uparrow$ \\
Ukraine & 145 & 147 & 149 & 152 & $137(15) \uparrow$ \\
\hline
\end{tabular}

Rating is based on indicators in 11 areas of business regulation.

In 2013, the improvement of the investment climate was achieved by simplifying the procedures in the field of construction and migration policy, a significant reduction of the cost of connecting new investment projects to the electricity grid, engineering and communication infrastructure. There have been passed laws aimed to improve customs administration and to liberalize the control of foreign investment and criminal law in the economic sphere. Russian Ministry of Economic Development has launched the mechanism of creation the institution of investment at the federal and regional levels. There was an increase in investments of international development institutions in priority for the Russian side economic industries and other. 
Russia has moved up 12 positions in the rating of Doing Business (from 124 places in 2010 to 112 place in 2013) by the activation of the investment policy and has become among the 25 countries of progress in improving the investment climate (Table 2).

Table 2. Dynamic of indicators doing business rating

\begin{tabular}{lll}
\hline Components Doing Business rating & 2012 & 2013 \\
\hline Enforcing contracts & 12 & $11(1) \uparrow$ \\
Property registration & 45 & $46(1) \downarrow$ \\
Construction permits & 180 & $178(2) \uparrow$ \\
Resolution insolvency & 61 & $53(8) \uparrow$ \\
Taxation & 94 & $64(30) \uparrow$ \\
Enterprises registration & 105 & $101(4) \uparrow$ \\
Crediting & 97 & $104(7) \downarrow$ \\
Investor protection & 114 & $117(3) \downarrow$ \\
International trade & 161 & $162(1) \downarrow$ \\
Connection to the electricity supply system & 184 & $184(0)-$ \\
\hline
\end{tabular}

Foreign investors prefer not risky strategies and focus investments on the following areas of the economy: mineral extraction; transport and communications; manufacturing; wholesale and retail trade; real estate transactions. It accounts for over $50 \%$ of all investments (Table 3 ).

Table 3. Priority economic activities for foreign investors

\begin{tabular}{|c|c|c|c|}
\hline \multirow{2}{*}{$\begin{array}{l}2005 \text { г. } \\
\text { Type of economic activity }\end{array}$} & \multirow[b]{2}{*}{$\%$} & \multicolumn{2}{|l|}{2012 г. } \\
\hline & & Type of economic activity & $\%$ \\
\hline Transport and communications & 20,25 & Production of fuel and energy minerals & 21,71 \\
\hline Production of fuel and energy minerals & 15,79 & Transport and communications & 12,47 \\
\hline Metallurgical production & 12,94 & Metallurgical production & 8,26 \\
\hline $\begin{array}{l}\text { Manufacture of food products, beverages and } \\
\text { tobacco }\end{array}$ & 6,42 & Real estate operations, renting and services & 7,88 \\
\hline Real estate operations, renting and services & 6,41 & $\begin{array}{l}\text { Production and distribution of electricity, gas } \\
\text { and water }\end{array}$ & 7,55 \\
\hline $\begin{array}{l}\text { Production and distribution of electricity, gas } \\
\text { and water }\end{array}$ & 5,51 & $\begin{array}{l}\text { Wholesale and retail trade; repair of vehicles, } \\
\text { motorcycles and personal and household } \\
\text { goods for personal use }\end{array}$ & 6,60 \\
\hline $\begin{array}{l}\text { Wholesale and retail trade; repair of vehicles, } \\
\text { motorcycles and personal and household } \\
\text { goods for personal use }\end{array}$ & 5,04 & $\begin{array}{l}\text { Manufacture of food products, beverages and } \\
\text { tobacco }\end{array}$ & 3,70 \\
\hline Constructing & 2,09 & Constructing & 3,73 \\
\hline
\end{tabular}

In 2012 the main countries-investors were-Cyprus, Netherlands, Luxembourg, Germany, China, United Kingdom, Virgin Islands (British), Ireland, Japan, France. These countries account for $85 \%$ of total accumulated foreign investment (FSSS, 1999-2014; MEDRF, 2013).

\section{Results}

Attraction of foreign investments is carried by Russian enterprises-recipients in various ways. The main of them are: credits of foreign banks, commercial credits by the state guarantees, related credits (export financing), issue and placement of shares by the ADR programs, the use of the concession system.

Bank credit appears in the form of debt of sum of money (loans). At the same time loan repayment period, repayment obligation and the amount of interest on the loan are stipulated. This type of credit is usually available for special categories of borrowers. In particular, it may be provided by the bank which is involved in financing the international priority investment program. 
Reception of the credit from commercial entity is usually carried with provision of government guarantees. The Government is a guarantor of the company through affiliated organizations (ministries, foundations) and pays the loan in the case of no return.

Export financing (or related credits) is used by enterprises-initiators of investment projects to attract interested in exporting the products of foreign manufacturers of related equipment. Such investment projects can be realized in interstate credit lines (Russian-French, German-Russian "Hermes", etc.) which allow to overcome the mismatch between legal and economic standards of West countries and Russia. According to this scheme, the Russian company picks up the provider of required process equipment in the country, determined according to the requirements of the credit line, and signs a framework agreement with him. The requirements to the Russian side include the provision of the business plan prepared in accordance to international standards, financial guarantee of regional administration, and letters of Russian government. In the scheme is also involved: the foreign bank which finances its manufacturing equipment authorized insurance company which insures the loan, Russian authorized bank which provide the refinancing of the project. Complexities of the application of this method of financing are associated with a relatively high interest rate loan, significant costs for insurance and maintenance of refinancing of the authorized bank, as a result a total interest rate may be $25-30 \%$. In addition, the daunting task (in particular for the distal regions) is to get the letter of the Russian government.

Issue and placement of shares among the foreign investors assume to purchase equity share of enterprise by foreign investor. Selling the part of shares to the investor, thus the company sells part of its property. The investor gets the right to participate in the main direction of the business policy of the company.

In the process of arranging financing through attraction foreign direct investment, there are situations when the placement of primary or additional issue of shares of the company is not possible due to several factors:

- the presence of the jurisdiction of legislative restrictions of direct investor in the country on export the capital;

- the lack of Russian subsidiary of investor, which can be the buyer of shares transferred to strategic investor-the management company;

- the presence of significant risks associated with safekeeping owned direct investor's securities;

- the presence of non-optimal mechanisms of calculating and converting dividends and other distributions for the direct investor from the equity of enterprise.

One of the methods of attracting foreign direct investment for effectively working Russian enterprises is the issue and placement the global depository receipts (GDR) and American Depository Receipts (ADR) on shares of Russian companies among the potential strategic investors. Issue of depositary receipts for issuing the shares of issuer permits foreign investors to gain a controlling stake of the investment object and at the same time minimizes the risks associated with circulation of their securities, which will be regulated by national and also international norms.

A promising mechanism for attracting foreign investments is to use the concession system in the development of compensation agreements, agreements of production sharing, project financing schemes, etc. Effective use of the concession system, which allows an optimal distribution of income and risks between the participants of investment, can significantly increase the flow of investments in the real sector of the Russian economy.

In Russia was made an important step in formation of legislative framework of realization the partnership between the state and private business in the form of concessions after the adoption in July 2005 the Federal Law \# 115-FL "On Concession Agreements". The main feature of such agreements is the participation of the state or the authorized state agency with a private company-investor. This form of relations will suit the foreign investors who are afraid to invest in public facilities. One of the positive aspects of the concession areas is that you can terminate the concession contract only through the court and only in the case of breach of the agreement which is clearly defined in the contract between the investor and the state.

It should be noted that the maintenance of a concession contract has to be predetermined by investment policy of the country directed on attraction of investment resources on construction of new and modernization of operating productions which for various reasons aren't invested or invested in insufficient volume by various categories of investors, but are necessary for the balanced development of national economy. Concessions have to provide the main requirements of development of national economy and its regions. We are solidary with M. A. Nemchaninova's opinion that the effective state investment policy and a guarantee of stability will lead to that foreign investments in the form of concessions can become a basis of modernization not only region economy, but also to nominate Russia to a role of the leading importer of direct foreign investments (Kolmykova, 2011). 
The agreement on the section of production is the contract according to which the Russian Federation provides to the subject to business activity (investor) on a paid basis and for a certain term exclusive rights to searches, investigation, production of mineral raw materials on the site of a subsoil specified in the agreement, and on conducting the works connected with it, and the investor undertakes to carry out the conduction the specified works at own expense and on the risk. The agreement defines all necessary conditions connected with using subsoil, including conditions and an order of the section of made production between the agreement parties. The parties of such agreement are: on the one hand-the Russian Federation on behalf of which in the agreement act the Government of the Russian Federation, or the bodies authorized by it, on the other hand-investors-legal entities and created on the basis of the contract on joint activity and not having the status of the legal entity, the associations of the legal entities which are carrying out an investment of own, loan or raised funds in searches, investigation and production of mineral raw materials and being users of a subsoil on the terms of the agreement. The winner of auction is the participant who has offered the highest price for the right of conclusion of agreement. The parties have to provide a condition in the agreement that not less than 70 percent of processing equipment in value terms for mining, their transportation and the processing acquired and (or) used by the investor for performance the work on the agreement, have to be the Russian origin (doesn't extend on use of objects of the main pipeline transport, construction and which acquisition aren't provided by the agreement).

\section{Discussion}

All reduced forms of attraction of foreign investments have long-term strategic character. They are capable to raise funds of foreign investors on the solution of structural branch problems, to promote acceleration of reduction of a technological gap with the leading industrial countries. Seeing in these forms of cooperation a positive orientation on the solution of strategic tasks on stabilization and lifting of the Russian economy, it is necessary to carry out their choice taking into account the purposes set by investor. Not all forms of attraction of investments can be used at different levels. So at the level of the separate enterprise there is no opportunity to use such forms of attraction of foreign investments as, for example, concession or free economic zone creation. Thus, various forms can be used for attraction of the foreign capital; however the main is creation of the enterprises in whole or in part belonging to foreign investors.

Essential value for activation of investors including foreign, is the accounting of features of regional investment policy. In particular Y. I. Treshchevsky and V. M. Kruglyakova have pointed to this circumstance.

So, Russia takes the 60th place among 187 studied countries in a rating of country investment risks appropriated by the Euro money magazine in 2012 .

It was noted that in recent years Russia had lost notable number of real foreign investors who wished to make investments in the Russian enterprises, but were compelled to refuse it (Kolmykova, 2011). The reasons for failure are:

- high costs and, as a consequence, the lack of competitiveness of production in Russia;

- difficult methods of registering of investments in Russian companies;

- obstinacy of the Russian partners, and also their inadequate assessment of a contribution of the Russian side;

- strong difference between words and affairs of the Russian heads and officials;

- unavailability of heads of the Russian enterprises to specific actions and cooperation with foreign investors.

\section{Conclusion}

The carried-out theoretical and factual analysis of a state and dynamics of foreign investments into Russia showed that the main directions of improvement of management of them are:

1) The simplification of procedures for obtaining building permits

Simplification of construction procedures-the major step to improvement of investment climate which allows reducing date of receipt of the construction license and costs of investors of their passing. Despite a number of the taken measures, the sphere of construction is still characterized by high level of administrative barriers. Government of the Russian Federation has approved the action plan for improving enforcement and licensing and government services in the area of urban development activity. Part of the measures already implemented.

2) Improving customs administration

The quality of customs administration directly influences on the assessment of the business environment. It is necessary to create the transparent system and to establish clear in understanding and simple for application not corruption standard instructions, to reduce of powers of customs authorities regarding actions at own discretion, 
especially in cases when such decisions can lead to a tightening of terms of passing of customs registration. Since July 1, 2010 the Customs code of the Customs union took effect which has consolidated the main norms of customs administration. In development of the Customs code in November, 2010 was adopted the law "On Customs Regulation in the Russian Federation" where the list of documents which can be requested by customs authorities for export and import was legislatively fixed; the term of release of non-oil goods was reduced from 20 to 4 o'clock, the number of necessary documents is reduced from 14 to 7 ; import and export of scientific commercial samples was simplified; the fixed cost (5000 rubles) was set for goods not imposed by import taxes, regardless of their cost, etc. is established.

The following steps in this direction are: development and acceptance the system of indicators of an assessment of efficiency of customs authorities, establishment of uniformity of the legislation of member countries of the Customs union and transparency of customs administration, and also creation of equal conditions of business for managing subjects and increase of positive perception of integration processes.

3) Increase of availability of energy infrastructure.

Infrastructure restrictions-one of the most essential negative factors influencing on investment climate in the country. Thus, in 2008 the cost of grid connection to the Moscow electricity grid was about 100000 rubles for 1 $\mathrm{kW}$ of the attached power. This price was very high for the majority of consumers (citizens and subjects of small business), and was the highest in the world for services of this sort. For the purpose of situation improvement since 2009 a number of the actions was realized which had led to tariff decrease for technological accession to electric grids for consumers to $15 \mathrm{~kW}$ from 7 thousand rubles to 550 rubles; the number of accessions to electric grids increased in 2011 compared to 2008 from 87 thousand to 168 thousand.

4) The development of business environment in the regions

Interest of the regional authorities is necessary in attracting investors as in the conditions of the competition for limited investment resource it is the instrument of creation new workplaces and the expansion of profitable base of regional and local budgets, and finally the improvement the quality of life. The agency of strategic initiatives has developed the standard of regional policy for development business environment providing uniform rules of supporting the business in subjects of the Russian Federation: the adoption of investment strategy and region memorandum; the adoption the regional law on protection the rights and mechanisms of support of investors; the adoption the regional law of assessment of regulating influence; creation of council for improvement of investment climate; creation the structure of attraction investments (regional corporation of development); creation of training centers, qualification confirmations; continuous information maintenance of investment policy of the region. The World Bank conducts research by request of the Ministry of Economic Development of the Russian Federation in 30 subjects of the Russian Federation by a technique Doing Business directed on an assessment of ease of conducting business activity. The results of this work will allow the regional authorities to reveal problem sites of investment climate, and also to develop and realize actions for their elimination, taking into account the international experience.

\section{5) Optimization of migratory procedures}

Migratory rules were one of the main demotivating factors in attraction foreign experts that provided to the deficiency of competences of high-tech and other industries where there was a need for professionals with specialized experience. The definition of this category of foreign specialists was provided to the migratory legislation to stimulate the attraction in national economy high qualified foreign specialists and to them was provided: the reduction of terms of obtaining work permits and visas from 1 year to 20 days, the increase of maximum periods of validity of visas and work permits from 1 year to 3 years with the opportunity of extension; cancellation of quotas, permits for employers for attracting foreign worker and coordination with employment agencies; the status of the resident and payment of personal income tax rate of $13 \%$ (instead of 30\%) from the first work day under the contract; the possibility of receiving residence permit in the simplified order, etc.

6) Tax stimulation

Tax policy should be aimed at creating conditions for maintaining sustained economic growth and for modernization Russian economy through implementation of stimulus measures directed on development the new industries, upgrading the existing, the increase of innovative activity and investment in human capital. The main measures were taken in:

- elimination of administrative barriers, creation favorable conditions for execution by the taxpayer of the duties and changes are made to the legislation-rules of control of the transfer prices are changed for prevention of 
outflow of the capital; the additional bases are entered for granting a delay (payment by installments) on payment of federal taxes;

- support the investments in researches and modernization industries is exempt from property tax efficient equipment for 3 years from the date of commissioning; provides the possibility of canceling the tax accounting of the value of intangible assets of innovation orientation during two years;

- support for the small and medium business is increased the limit income of taxpayer restricted his right to use the simplified taxation system from 20 million rubles to 60 million rubles; cumulative rate of compulsory insurance premiums for small businesses has been reduced from 26 to $20 \%$;

- stimulations of investments into the human capital is authorized to recognize expenses on training concerning persons with whom the employment contract will be signed after training; it is temporarily authorized to refer on expenses compensation to workers of expenses for payment of percent on loans (credits) for acquisition or housing construction;

- stimulation innovative activity and support of companies with prevailing application of intellectual work are temporarily established the lowered rates of insurance premiums for a number of taxpayers (IT, residents of TVZ OEZ, the small innovative companies, the simplified tax system in the production sphere, engineering); the preferential tax mode is established for residents of the innovative center "Skolkovo" for 10 years;

- stimulation of venture investment are exempted from a profit tax of the organizations income from implementation of the securities which aren't traded on the organized market, and also outstanding shares of the hi-tech companies, on condition of holding period not less than 5 years;

- maintenance of socially important sectors and improve of taxation of separate categories of taxpayers, industries and types of production set at $0 \%$ for income tax for organizations in the field of education and health; expanded "geographical" list of oil fields, which operates a zero tax rate of mineral extraction tax; indexed excise rates, significantly increased rates on alcohol and tobacco products;

- improvement of depreciation policy opportunity to charge depreciation by a method of the decreasing rest on the integrated depreciation groups that allowed to write off for expenses the most part of expenses for acquisition of fixed assets in an initial stage of their operation is entered

- improvement of depreciation policy introduced, the possibility of charge depreciation the declining balance method is entered of depreciation groups that allowed expensed most of the cost of acquisition of fixed assets in the initial period of their operation; increased size of the "depreciation premium" up to $30 \%$ of the original value of fixed assets relating to the active part of production funds; the terms of useful services are reduced of fixed assets; the opportunity to apply to the main norm of depreciation is given of the fixed assets having high power efficiency, and also the fixed assets used for carrying out researches, the raising coefficient.

The questions related with taxation of financial tools and investors' activity and professional participants of the securities market within the creation International Financial Center in Russian Federation need to be addressed. It is necessary to change the tax burden on the resource industries in order to develop the industrial potential of the country and to increase the investment attractiveness of non-oil sectors of the economy. For stimulation the development of business projects it is necessary to work introduction option for them tax vacation on a profit tax, the property tax of the organizations and a land tax; work out the issue of gradual transition to the complete abolition of corporate property tax in respect of the active (moveable) assets for all taxpayers to stimulate them to invest in modernization of production facilities.

7) Development of the corporate legislation

In 2010 was entered into force the amendments to the Federal Law "On the Securities Market", expanding the list of essential facts from 12 to 50 which were subject to mandatory disclosure by issuers of securities. The bill was passed that authorizing the minority shareholders had access to the documents of controlling companies and establishing the procedure for "proactive audits."

It is important to establish the minimum requirements and standards of participation of business community in discussion the questions of state regulation of economic and investment activity, and also to specify the scopes of procedure of an assessment of regulating influence.

8) Decrease of administrative barriers

Numerous ratings and expert surveys of members the business community show that today administrative barriers are the main issue in the development of entrepreneurship, in the development of new businesses and 
finally in the formation of modern innovation economy in Russia. Excessive administrative barriers lead to the corruption of officials.

Since 2009, 69 types of business were transferred from permissive to notifying order. There was entered the possibility of submission of the notice in electronic form; the quantity of licensed kinds of activity was reduced from 89 to 49; the ban was introduced on carrying out planned inspections more often than one time in 3 years is imposed. As a result, the number of inspections of businesses decreased by $25 \%$. Audits of small and medium-sized enterprises are possible by controlling bodies and agreement with prosecutors. The term of inspections were limited. The Federal Service of accreditation was formed, which tasked with the formation of a unified national system of accreditation and monitoring the activities of accredited persons.

Next steps: reduction of excessive administrative procedures and actions, decrease of the number of required documents and optimize the interaction with the applicant, the elimination of limited period of validity of permissions, transition from licensing of some fields of activity to a notifying order of their implementation.

9) Development of criteria for assessing the effectiveness of heads of federal executive bodies to improve the investment climate

In Russian Ministry of Economic Development with the participation of business associations and experts of the World Bank were selected directions to develop a system of quantitative target indicators, including connection to the electricity grid, simplification of procedures of obtaining the construction license and input of objects in operation, customs administration. For heads of federal executive authorities responsible for improving the business environment were proposed criteria of assessing performance, reflecting the achievement of qualitative and quantitative indicators in terms of improving the investment climate. Currently, these criteria are being discussed with the federal executive authorities and representatives of business communities.

10) Cooperation with international development institutions

In competition for international financial resources Russia strengthened positions in work with some international institutes of development, in particular with the European bank of reconstruction and development. In 2011 was reached the maximum level of financing (of €2,9) the projects of European bank of reconstruction and development in Russia and investments of industry, trade and agriculture firstly exceeded the investments of financial sector; now EBRR projects portfolio in Russia is $€$ 9,5 billion.

11) Formation of institutions of improvement the investment climate

Among them:

- Russian fund of direct investments made for co-finance foreign investments in modernization the economy. The main priority of this fund is maximization profitability on the capital invested by the fund and co-investors. The fund participants in projects from 50 to 500 million dollars with share of less than $50 \%$. Capitalization of fund in 2011-\$ 2 billion, in 2012-2016-\$ 8 billion.

- Institute of the federal investment authorized for project support of foreign investors. Functions of the ombudsman perform the Russian Ministry of Economic Development. In the regions the functions of investment ombudsman are entrusted to vice plenipotentiaries of the President of the Russian Federation in the federal districts.

- Agency of Strategic Initiatives, created to promote in overcoming administrative barriers and attracting co-financing for promising commercial, social and infrastructure projects. Agency has developed the Standard of regional policy for development of business environment which is currently introducing in Russian regions. Also as a part of "National entrepreneurial initiative" is carried out the development of road maps on 22 spheres of state regulation which expected to improve the legislation and realization of measures aimed to achieve the results provided in legislative initiatives.

- Agency for ensuring export credits and investments, created to support Russian export and firstly to domestic high technical products (machinery, equipment and transport vehicles, construction and engineering services). The Agency will provide the insurance of $17.6 \%$ of Russian export, and in 2015 it must be $30 \%$.

- The Advisory Council of Foreign Investments in Russia-for attracting foreign investments in Russian economy, and also for creation decisions to improve the investment climate.

Russia needs innovative way of development, becoming the country in the world's leading economies with high level of welfare, developed infrastructure, a substantial share of high-technical sector in the country's GDP. 
Necessary condition of realization these tasks are scale investments in productions, new technologies, and education. Modern volumes of investments of $20.6 \%$ directed to fixed capital of GDP are clearly insufficient.

In this regard, the only way to ensure sustainable economic growth parameters is to create comfortable business environment for domestic and foreign investors.

\section{References}

Agency for Strategic Initiatives. (2012). Retrieved May 30, 2014, from http://www.asi.ru/en

FSSS. (1999-2014). Federal State Statistics Service of Russian Federation. Retrieved November 10, 2013, from http://www.gks.ru

Heckscher, E. (2007). In R. R. G. H. Findlay, H. L. Henriksson, \& M. Lundahl (Eds.), International Trade and Economic History. The MIT Press.

Kolmykova, T. S. (2011a). Innovations in solving problems of formation new reproductive contours of the national economy. Scientific and technical statements SPbSTU. Seria "Science and Education", 3(121), 45-49.

Kolmykova, T. S. (2011b). The main aspects of realization the strategy of innovative development of national industry system. News of Southwest State University, 6(39), 52-60.

Kruglyakova, V. M. (2010). State regulation of investment activity: Theory, domestic and foreign practice (pp. 180). Voronezh, VSPU.

Maier, R. (2002). Knowledge Management Systems. Information and Communication Technologies for Knowledge Management (pp. 35-40). Springer, Verlag Berlin, Heidelberg.

Matusiak, K. (2005). High tech, Innovation and technology transfer (pp. 48-51). Glossary of Terms. PARP. Warsaw.

Mil, Dz. (1981). Principles of Political Economy (pp. 49-68). V.3. Moscow. INFRA.

Ministry of Economic Development of the Russian Federation. (2013). Retrieved June 25, 2014, from http://www.economy.gov.ru/wps/wcm/connect/economylib4/en/home

Nemchinova, M. A. (2012). Concession as a form of attracting investment in the regional economy. Russian entrepreneurship, 12, 168-172.

Preobrazhensky, B. G. (2008). The integration of Russian regions into the world economy: Forms, trends, factors, tools. Voronezh. Scientific book, 296.

Preobrazhensky, B. G., \& Zelenskay, S. G. (2012). Formation mechanism attraction foreign investments in the Russian economics (macroeconomic paradox Russian mechanism attraction foreign investment). Region: Systems, economics, management, 2, 24-40.

Ricardo, D. (1993). Principles of political economy and taxation (pp. 27-40). V.1 Moscow.

RVCA. (2014). Russian Venture Capital Association. Retrieved May 30, 2014, from http://www.rvca.ru/eng

Stepanchenko, A. V. (2013). Foreign investments in strategically sector of the economics: Some problems of reconciliation of the law on strategically foreign investment. Business, management and law, 1(27), 78-84.

The National Union of business angel. (2009). Retrieved May 30, 2014, from http://www.russba.ru

Treschevsky, Y. I. (2010a). Analysis of the dynamic of foreign investments in Russian regions. Terra Economics. Economic journal of Rostov State University, 1, 151-159.

Treschevsky, Y. I. (2010b). The modern practice of state regulation of investment activity in the Russian regions: General and special. Modern economy: Problems and solutions, 3(3), 32-43.

Valras, L. (2000). Elements of pure political economy and theory of social wealth (pp. 77-98). Moscow: Izograf.

Zakrzewska-Bielawska, A. (2010). High Technology Company. Concept, Nature, Characteristics (pp. 12-27). Department of Management Technical University of Lodz, Poland.

\section{Copyrights}

Copyright for this article is retained by the author(s), with first publication rights granted to the journal.

This is an open-access article distributed under the terms and conditions of the Creative Commons Attribution license (http://creativecommons.org/licenses/by/3.0/). 